\title{
Interaction of Atriopeptin III and Vasopressin on Calcium Kinetics and Contraction of Aortic Smooth Muscle Cells
}

Harald Meyer-Lehnert, Carlos Caramelo, Phoebe Tsai, and Robert W. Schrier

Department of Medicine, University of Colorado School of Medicine, Denver, Colorado 80262

\section{Abstract}

The cellular mechanism of the vasodilatory action of atriopeptin III (APIII) on vasopressin (AVP)-induced $\mathrm{Ca}^{2+}$ mobilization and cell shape change in cultured vascular smooth muscle cells (VSMC) was studied. APIII $\left(10^{-8} \mathrm{M}\right)$ attenuated the increase of intracellular free $\mathrm{Ca}^{2+},\left[\mathrm{Ca}^{2+}\right]_{i}$, induced by $10^{-8} \mathrm{M}$ AVP (234.0 \pm 14.8 vs. $310.0 \pm 28.4 \mathrm{nM}, P<0.01)$. Similar results were obtained in ${ }^{45} \mathrm{Ca}^{2+}$ efflux experiments. APIII $\left(10^{-7}\right.$ M), however, did not alter AVP-induced inositol trisphosphate $\left(\mathrm{IP}_{3}\right)$ production, although the levels of inositol-1-phosphate were significantly reduced. The effect of APIII to block or attenuate AVP-induced $\mathrm{Ca}^{2+}$ mobilization was associated with an inhibition of AVP-stimulated cell shape change. The effect of atrial natriuretic factor (ANF) on cell shape, however, occurred at lower ANF concentrations than the effect on the $\mathrm{Ca}^{2+}$ mobilization. APIII stimulated production of cyclic guanosine monophosphate (cGMP) in VSMC. The effect of APIII on AVP-stimulated $\mathrm{Ca}^{2+}$ mobilization was partially mimicked by the stable nucleotide 8-bromo cGMP and was not affected by the soluble guanylate cyclase inhibitor, methylene blue $\left(1^{-4}\right.$ M). These results suggest that APIII exerts its vasodilatory effect, in part, by interference with vasopressor-stimulated $\mathrm{Ca}^{2+}$ mobilization in vascular smooth muscle cells, perhaps by stimulating particulate guanylate cyclase and cGMP. However, an effect of ANF on the contractile mechanism at a site independent of $\mathrm{Ca}^{2+}$ release is also suggested by the present results.

\section{Introduction}

The isolation, characterization, and amino acid sequencing of the atrial natriuretic peptides from atrial cardiocytes has stimulated considerable investigation into the mechanism of action of these substances (1-3). In addition to the diuretic and natriuretic effects of these peptides, specific binding sites have been demonstrated for these atrial peptides in a variety of vascular tissues (4-8). Although a vasoconstrictor effect of atrial natriuretic factor (ANF) ${ }^{1}$ has been shown in certain experimental

Parts of this work were presented at the plenary session of the 19th Annual Meeting of the American Society of Nephrology, 7-10 December 1986, Washington, DC.

Address reprints requests to Dr. Schrier, C281, University of Colorado School of Medicine, 4200 E. 9th Avenue, Denver, CO 80262. 1988.

Received for publication 22 June 1987 and in revised form 2 May

1. Abbreviations used in this paper: AII, angiotensin II, ANF, atrial natriuretic factor; APIII, atriopeptin III, AVP, arginine vasopressin; 8-bcGMP, 8-bromo cGMP; IP, inositol phosphate(s); MIX, 3-isobutyl-1-methylxanthine; PSS, physiological saline solution.

J. Clin. Invest.

(c) The American Society for Clinical Investigation, Inc.

$0021-9738 / 88 / 10 / 1407 / 08 \$ 2.00$

Volume 82, October 1988, 1407-1414 settings (9), in general ANF has been found to exert a vasodilatory action (3-14). This vasodilation by ANF, however, seems to be most readily demonstrable in the presence of vasoconstrictors $(3,9,12)$.

This latter observation, therefore, suggests that ANF may exert its vasodilatory effect, at least in part, by interfering with the cellular action of vasoconstrictors. This possibility was tested in the present study by examining the interaction of arginine vasopressin (AVP) and atriopeptin III (APII), a 24amino acid peptide with well-established vasodilatory properties (5), on ${ }^{45} \mathrm{Ca}^{2+}$ efflux, ${ }^{45} \mathrm{Ca}^{2+}$ influx, cytosolic free $\mathrm{Ca}^{2+}$, and cellular contraction of rat vascular smooth muscle cells in culture. In addition, since it has been suggested that cyclic guanosine monophosphate (cGMP) may be an intracellular mediator of $\operatorname{ANF}(15,16)$, the effect of the stable nucleotide analogue, 8-bromo cGMP, on AVP-mediated cellular $\mathrm{Ca}^{2+}$ kinetics and cell contraction was also examined. Finally, in view of results showing a decrease of $\mathrm{Ca}^{2+}$ mobilization by AVP in the presence of ANF, we studied the AVP-induced production of inositol trisphosphate $\left(\mathrm{IP}_{3}\right)$, the putative mediator of $\mathrm{Ca}^{2+}$ release, both in the presence and absence of ANF.

\section{Methods}

APIII was obtained from Peninsula Laboratories, Inc. (Belmont, CA). ${ }^{45} \mathrm{CaCl}_{2}$ was purchased from New England Nuclear (Boston, MA). 8-bromo cGMP, AVP, methylene blue, quin 2, and quin 2-acetoxy methylester (quin 2-AM) were purchased from Sigma Chemical Co. (St. Louis, MO) and fura 2 was from Molecular Probes, Inc. (Eugene, OR). $\left[{ }^{3} \mathrm{H}\right]$ Inositol and radiolabeled inositol phosphates were purchased from Amersham Corp. (Arlington Heights, IL). Digitonin was obtained from Calbiochem-Behring Corp. (LaJolla, CA).

Preparation of aortic smooth muscle cells and cell culture. Rat aortic smooth muscle cells were isolated using a modified method originally described by Chamley et al. (17). The thoracic aortas from six to eight male Sprague-Dawley rats were incubated at $37^{\circ} \mathrm{C}$ for 30 min in $7.5 \mathrm{ml}$ of Eagle's minimum essential medium (MEM) containing $2 \mathrm{mg} / \mathrm{ml}$ collagenase (Cooper Biomedical, Inc., Malvern, PA; 218 $\mathrm{U} / \mathrm{mg}$ ). After dissecting the adventitia, the aortas were minced with sterile razor blades and incubated again at $37^{\circ} \mathrm{C}$ in Eagle's MEM (2 $\mathrm{mg} / \mathrm{ml}$ collagenase) for $2.5-3 \mathrm{~h}$ under continuous stirring. After this incubation the resulting single cell suspension was centrifuged for 5 min at $1,000 \mathrm{rpm}$. The cell pellet was resuspended in fresh incubation medium without collagenase. This procedure was repeated twice. The cells were plated onto $35-\mathrm{mm}$ cultures dishes at a density of 2.5-3.0 $\times 10^{5}$ cells/dish and grown at $37^{\circ} \mathrm{C}$ in a humidified atmosphere of $95 \%$ air and $5 \% \mathrm{CO}_{2}$. Eagle's MEM, supplemented with $10 \%$ fetal calf serum, $100 \mathrm{U} / \mathrm{ml}$ penicillin, and $100 \mu \mathrm{g} / \mathrm{ml}$ streptomycin was used as culture medium. Cell viability was checked by the exclusion of trypan blue $(0.3 \%)$ and always exceeded $95 \%$. The cultures reached confluence after 7-10 d and were then used for experiments. Only primary cultures were used because vascular smooth muscle cells may lose their contractility when subcultured (18).

Quin 2 and fura 2 loading and fluorescent measurements. For measurements of intracellular free $\mathrm{Ca}^{2+},\left[\mathrm{Ca}^{2+}\right]_{i}$, levels, aortic smooth muscle cells were grown on round glass coverslips (13-mm diam). Upon confluence, the coverslips were washed twice with MEM without fetal calf serum. The coverslips were then incubated with serum- 
free MEM containing $15 \mu \mathrm{M}$ quin 2-AM for $60 \mathrm{~min}$ at $37^{\circ} \mathrm{C}$ in $95 \%$ air and $5 \% \mathrm{CO}_{2}$. At the end of the loading period, the coverslips were washed three times with physiological saline solution (PSS; $140 \mathrm{mM}$ $\mathrm{NaCl}, 4.6 \mathrm{mM} \mathrm{KCl}, 1.0 \mathrm{mM} \mathrm{MgCl}, 2.0 \mathrm{mM} \mathrm{CaCl}_{2}, 10 \mathrm{mM}$ glucose, $10 \mathrm{mM}$ Hepes, $\mathrm{pH}$ 7.4) and inserted into disposable fluorescence cuvettes containing $3 \mathrm{ml}$ PSS. The cuvettes were placed in the thermostated holder of a fluorescence spectrophotometer (650-10S,(PerkinElmer Corp., Norwalk, CT). Fluorescence of quin 2-loaded cells was measured using an excitation wavelength of $339 \mathrm{~nm}$ (slit $5 \mathrm{~nm}$ ) and an emission wavelength of $492 \mathrm{~nm}$ (slit 15-20 nm) (19).

The complete intracellular hydrolysis of quin 2-AM was judged by scanning the emission spectrum of quin 2 from 400 to $600 \mathrm{~nm}$ in the loaded cells. The cells exhibited a complete spectral shift peaking at $490-500 \mathrm{~nm}$ at the end of the loading procedure. None of the agents tested affected the fluorescence emission of nonloaded cells, nor did they have any significant fluorescence of their own.

A slow spontaneous decrease in fluorescence emission of quin 2loaded cells $[9.3 \pm 0.5 \%$ (mean $\pm \mathrm{SE}, n=11)$ of total $\mathrm{Ca}^{2+}$-dependent fluorescent emission] after 2 min was observed due to photo bleaching of the probe and fluorescence tracings were corrected (during each experimental period) for the calculation of $\left[\mathrm{Ca}^{2+}\right]_{i}$.

Cellular quin 2 concentration was estimated using a quin 2 free acid standard in the presence of nonloaded cells. Assuming an intracellular water space of $\sim 0.25 \mu \mathrm{l} / 10^{5}$ cells $(20)$, the calculated cellular quin 2 concentrations were $1.35 \pm 0.24 \mathrm{mM}($ mean $\pm S E, n=11)$.

A value of $115 \mathrm{nM}$ was used as the dissociation constant $\left(K_{d}\right)$ of the quin $2-\mathrm{Ca}^{2+}$ complex and $\left[\mathrm{Ca}^{2+}\right]_{i}$ was calculated as described $(19,21)$. Leakage of quin 2 from the cells was excluded by adding $5 \times 10^{-4} \mathrm{M}$ $\mathrm{MnCl}_{2}$ to quench the fluorescence of any extracellular quin 2. This maneuver did not affect the basal fluorescence.

For the fura 2 measurements, the monolayers on coverslips were incubated for $45 \mathrm{~min}$ at $37^{\circ} \mathrm{C}$ with MEM containing no FBS and with $4 \mu \mathrm{M}$ fura $2 \mathrm{AM}$. The monolayers were then washed three times with MEM containing no fura 2 and incubated another $15 \mathrm{~min}$ at $37^{\circ} \mathrm{C}$ to allow time for any nonhydrolyzed fura 2-AM to diffuse from the cells. Before measurement, the coverslips were rinsed again with PSS containing $2 \mathrm{mM} \mathrm{Ca}^{2+}$. Fluorescence was measured at $37^{\circ} \mathrm{C}$ using the same equipment and conditions as for quin 2 determinations, at an emission wavelength of $500 \mathrm{~nm}$ and excitation wavelengths of 342 and $380 \mathrm{~nm}$. Autofluorescence was measured in similar cells which had not been loaded with fura 2 and was $<10 \%$ of the total fluorescence of fura 2-loaded cells in all the experiments. $\left[\mathrm{Ca}^{2+}\right]_{i}$ was calculated as described by Grynkiewicz et al. (22). In this and the following sets of experiments, unless otherwise stated, cells were preincubated in the presence or absence of ANF by $5 \mathrm{~min}$, before the addition of the effectors and ANF was simultaneously added with the effectors. Preincubation with ANF avoids any possible interference by AVP on other mediators of ANF-mediated CGMP generation (23).

${ }^{45} \mathrm{Ca}^{2+}$ efflux. The culture medium was removed by aspiration and cell monolayers were rinsed twice with $1 \mathrm{ml}$ PSS and loaded with $8 \mu \mathrm{Ci}$ of ${ }^{45} \mathrm{Ca}^{2+}$ in $1 \mathrm{ml}$ of PSS at $37^{\circ} \mathrm{C}$ for $3 \mathrm{~h}$. Then the cultures were rapidly rinsed 10 times with $1 \mathrm{ml}$ of PSS and another $1 \mathrm{ml}$ of PSS was added. The medium was removed and replaced with $1 \mathrm{ml}$ of PSS at 1,2,3, and $4 \mathrm{~min}$ and thereafter at 30-s intervals. Hormones and other compounds were added as indicated during the time course of ${ }^{45} \mathrm{Ca}^{2+}$ efflux. The amount of ${ }^{45} \mathrm{Ca}^{2+}$ released from the cells in each time interval was measured by liquid scintillation counting.

${ }^{45} \mathrm{Ca}^{2+}$ uptake. The culture medium was removed by aspiration and the cells were washed twice with $1 \mathrm{ml}$ of PSS. Then the cells were incubated for $5 \mathrm{~min}$ with $2 \mu \mathrm{Ci}$ of ${ }^{45} \mathrm{Ca}^{2+}$ in the presence or absence of effectors in $1 \mathrm{ml}$ of PSS. To terminate the uptake, external ${ }^{45} \mathrm{Ca}^{2+}$ was removed by rinsing the dish five times at $4^{\circ} \mathrm{C}$ with $\mathrm{Ca}^{2+}$-free PSS containing $2 \mathrm{mM}$ EGTA. Intracellular radioactivity was extracted with $1 \mathrm{ml}$ of sodium dodecyl sulfate-containing alkaline solution and measured by liquid scintillation counting.

Measurement of $c G M P$ and $C A M P$. The cells were incubated for 10 min at $37^{\circ} \mathrm{C}$ in PSS containing $0.5 \mathrm{mM}$ 3-isobutyl-1-methylxanthine (MIX), with or without APIII. The reaction was terminated by adding
$100 \mu l$ of $0.1 \mathrm{~N} \mathrm{HCl}$ to disrupt the cells. The cells were scraped with a rubber policeman and centrifuged. The supernatants were saved for determination of CGMP and CAMP which was done by radioimmunoassay with commercial kits by New England Nuclear.

Protein was determined in all studies by the method of Lowry et al. (24).

Measurement of inositol phosphates. After cells were grown to confluence, the culture media of each dish was replaced with $1 \mathrm{ml}$ of inositol-free medium containing $10 \mu \mathrm{Ci}$ of myo- $2\left[{ }^{3} \mathrm{H}\right]$ inositol (specific activity $16.3 \mathrm{Ci} / \mathrm{mmol}$ ), and cells were incubated during $24 \mathrm{~h}$. It has been previously shown that steady-state labeling occurs by $24 \mathrm{~h}$. At the moment of the experiment, culture media was aspirated and replaced with $500 \mu \mathrm{l} /$ dish of $37^{\circ} \mathrm{C}$ PSS containing $10^{-8}$ or $10^{-7} \mathrm{M}$ AVP. The reaction was stopped after $30 \mathrm{~s}$ using $500 \mu \mathrm{l}$ of ice-cold trichloroacetic acid (20\% solution). Cells were scraped using an Eppendorf pipette top and aliquots were taken for protein determination. In the experiments using ANF, cells were preincubated with $10^{-7} \mathrm{M}$ ANF in PSS for 5 min; after this period, this solution was replaced by PSS containing $10^{-7} \mathrm{M}$ ANF and $10^{-8}$ or $10^{-7} \mathrm{M}$ AVP.

The samples were centrifuged at $1,000 \mathrm{~g}$ for $10 \mathrm{~min}$. The supernatant, containing inositol phosphates, was washed three times with an equal volume of ether and stored at $-20^{\circ} \mathrm{C}$ until analysis, which was performed during the same week of the extraction. The water-soluble fraction was thawed and brought to $\mathrm{pH} 6.0$ using Tris-base $(50 \mu \mathrm{M})$. The extracts were applied to columns containing $1 \mathrm{ml}$ of Dowex- $1(\times 8$, Formate form) and serially eluted with 1-ml aliquots of $\mathrm{CH}_{2} \mathrm{O}$, Borax ( $5 \mathrm{mM}$ disodium tetraborate, $60 \mathrm{mM}$ sodium formate), $0.2,0.5$, and $1.0 \mathrm{M}$ ammonium formate (in $0.1 \mathrm{M}$ formic acid) separating, respectively, inositol, glycero-phosphatidylinositol, inositol-1-phosphate, inositol bisphosphate, and $\mathrm{IP}_{3}(25)$; this last fraction includes 1,3,4and 1,4,5-IP $\mathrm{IP}_{3}$ and 1,3,4,5-inositol phosphate. Samples were collected and counted in a scintillation counter. The extraction procedure has been previously validated with radioactive phosphoinositides. Results were expressed as number of $\mathrm{IP}_{3}$ counts per milligram of protein.

Smooth muscle cell shape change. The change in cell shape of aortic smooth muscle cells was evaluated by using phase-contrast microscopy (IM, Carl Zeiss, Oberkochen, Federal Republic of Germany) and a digital imaging analysis system (Zidas, Carl Zeiss). The digitizer was calibrated with a micrometer scale for each experiment. Cell surface area was measured before and $20 \mathrm{~min}$ after the addition of any agent. These measurements were done in triplicate on each cell. Repeated measurements of the same cell yielded an average coefficient of variation of $\sim 1.5 \%$. Taking into account the spontaneously occurring change of cell shape and the variability in the image analysis, only a decrease in cell surface area of $>15 \%$ was considered a positive contractile response. $A \times 20$ objective was used for all contraction studies. The microscopic field was chosen randomly. At the time of the experiment, culture medium was aspirated and cells were washed twice with PSS. Cells were then incubated with $37^{\circ} \mathrm{C}$ PSS in the presence or absence of the effectors and cell shape change was evaluated at room temperature. In experiments with ANF, a 5 min preincubation was performed, as described previously.

Statistical analysis. Data are presented as mean \pm SEM and statisti$c a l$ analysis was performed with Student's $t$ test for paired and unpaired data. The Bonferroni correction was used for multiple comparisons. Results of the contraction studies were evaluated with the Wilcoxon rank sum test.

\section{Results}

Intracellular free $\mathrm{Ca}^{2+}$. The basal $\left[\mathrm{Ca}^{2+}\right]_{\mathrm{i}}$ in resting aortic smooth muscle cells using quin 2 was $152.3 \pm 9.4 \mathrm{nM}(n=27)$. Upon stimulation with AVP, there was a dose-dependent rapid increase in $\left[\mathrm{Ca}^{2+}\right]_{i}$ (Fig. 1), which returned to basal levels within 5-7 min. APIII $\left(10^{-8} \mathrm{M}\right)$ alone did not affect the basal free $\mathrm{Ca}^{2+}$ levels ( $145.4 \pm 8.7$ vs. $\left.152.3 \pm 9.4 \mathrm{nM}, \mathrm{NS}\right)$ either when the cells were preincubated with APIII for $10 \mathrm{~min}$ or when 


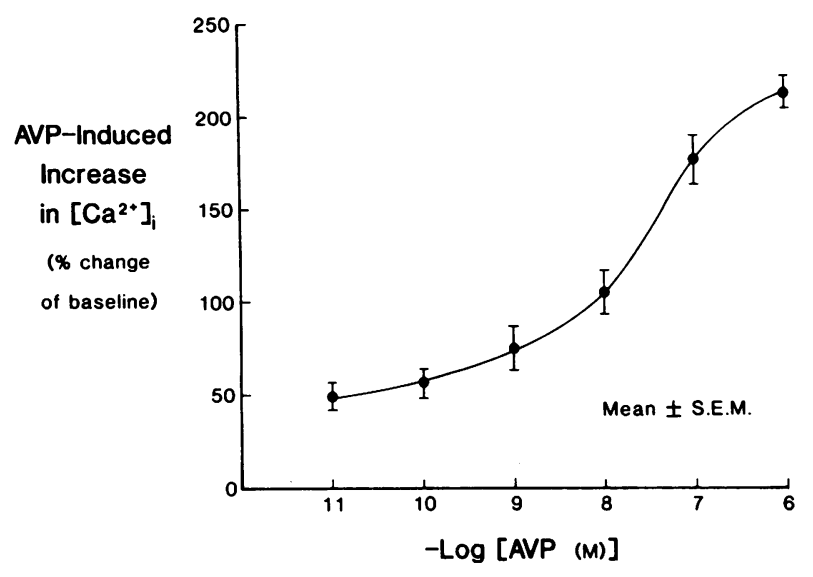

Figure 1. Dose-response curve for AVP-induced changes in $\left[\mathrm{Ca}^{2+}\right]_{i}$. Points represent the mean of the maximal change in $\left[\mathrm{Ca}^{2+}\right]_{i}$, expressed as percent increase over baseline. Each point represents the mean \pm SEM of 11-27 determinations in at least five separate cell cultures.

$\left[\mathrm{Ca}^{2+}\right]_{i}$ was measured directly after addition of APIII. In the presence of $10^{-7} \mathrm{M}$ AVP, ANF $\left(10^{-8} \mathrm{M}\right)$ had no effect on stimulated $\left[\mathrm{Ca}^{2+}\right]_{\mathrm{i}}(436.3 \pm 21.7$ vs. $418.4 \pm 19.1 \mathrm{nM}, \mathrm{NS})$. However, APIII $\left(10^{-8} \mathrm{M}\right)$ significantly attenuated the increase in cytosolic free $\mathrm{Ca}^{2+}$ induced by $10^{-8} \mathrm{M}$ AVP (Fig. 2) in a dosedependent manner. The mean peak value of $\left[\mathrm{Ca}^{2+}\right]_{i}$ with AVP $\left(10^{-8} \mathrm{M}\right)$ was $310.0 \pm 28.4 \mathrm{nM}$; it decreased to $234.0 \pm 14.8 \mathrm{nM}$ $(P<0.01)$ in the presence of APIII $\left(10^{-8} \mathrm{M}\right)$. No measurable lag time was observed before the onset of the effect of AVP in the presence of APIII. The following similar results were found in experiments measuring $\left[\mathrm{Ca}^{2+}\right]_{i}$ using fura 2 . Whereas APIII $\left(10^{-8} \mathrm{M}, 5-\mathrm{min}\right.$ preincubation) did not affect the $\left[\mathrm{Ca}^{2+}\right]_{\mathrm{i}}$ increase by $10^{-7} \mathrm{M} \mathrm{AVP}(\Delta 303.08 \pm 18.4$ vs. $\Delta 362.48 \pm 33.0 \mathrm{nM}$, NS, $n=3), 10^{-8} \mathrm{M}$ APIII significantly reduced the $\left[\mathrm{Ca}^{2+}\right]_{\mathrm{i}}$ peak by $10^{-8} \mathrm{M}$ AVP $(\Delta 168.9 \pm 20.25$ to $\Delta 104.32 \pm 22.0 \mathrm{nM}, P$ $<0.025, n=8$ ). Basal levels of $\left[\mathrm{Ca}^{2+}\right]_{\mathrm{i}}$ were not significantly affected by ANF $(86.6 \pm 5.7$ vs. $80.5 \pm 8.3 \mu \mathrm{M})$. In control experiments using angiotensin II (AII) as the cell activator, no effect of $5 \times 10^{-8} \mathrm{M}$ APIII was found in the $\left[\mathrm{Ca}^{2+}\right]_{i}$ peak produced by $10^{-7}$ AII $(\Delta 857.17 \pm 82.7$ without ANF vs. $\Delta 954.08 \pm 54.3 \mathrm{nM}$ with ANF $)$ and $10^{-8} \mathrm{M}$ AII $(\Delta 587.16 \pm 90.0$ without ANF vs. $\Delta 504.25 \pm 11.4 \mathrm{nM}$ with $\mathrm{ANF})$.
${ }^{45} \mathrm{Ca}^{2+}$ efflux. Preincubation $\left(5 \mathrm{~min}\right.$ ) of the cells with $10^{-8}$ $M$ APIII did not affect the spontaneous ${ }^{45} \mathrm{Ca}^{2+}$ efflux (data not shown). AVP $\left(10^{-8} \mathrm{M}\right)$ markedly increased ${ }^{45} \mathrm{Ca}^{2+}$ efflux within $30 \mathrm{~s}\left(1.64 \pm 0.15\right.$ vs. $2.59 \pm 0.37 \times 10^{3} \mathrm{cpm} / \mathrm{mg}$ protein per $30 \mathrm{~s}, n=5, P<.005$ ) (Fig. 3). The maximal increase was observed after $60 \mathrm{~s}$. Basal efflux rates were reached again after about $3 \mathrm{~min}$. In cells preincubated for $5 \mathrm{~min}$ with APIII $\left(10^{-8}\right.$ $\mathrm{M})$, the stimulatory effect of $\operatorname{AVP}\left(10^{-8} \mathrm{M}\right)$ was attenuated and only a slight insignificant increase was observed. APIII (5 $\times 10^{-9} \mathrm{M}$ ) significantly attenuated the response to AVP (Fig. 3). However, no effect of APIII $\left(10^{-8} \mathrm{M}\right)$ on $10^{-7} \mathrm{M}$ AVP-mediated $\mathrm{Ca}^{2+}$ efflux was detected $(4.69 \pm 0.41$ vs. $4.51 \pm 0.33$ $\times 10^{5} \mathrm{cpm} / \mathrm{mg}$ protein per $30 \mathrm{~s}, n=5$ ).

${ }^{45} \mathrm{Ca}^{2+}$ uptake. In Fig. 4, the ${ }^{45} \mathrm{Ca}^{2+}$ uptake in response to AVP alone, APIII alone, and AVP plus APIII are depicted. The uptake of ${ }^{45} \mathrm{Ca}^{2+}$ by aortic smooth muscle cells was measured over a period of $5 \mathrm{~min}$. AVP $\left(10^{-8} \mathrm{M}\right)$ significantly stimulated ${ }^{45} \mathrm{Ca}^{2+}$ uptake above spontaneous influx from $9.58 \pm 0.75$ to $13.04 \pm 0.92 \times 10^{3} \mathrm{cpm} / \mathrm{mg}$ protein per $5 \mathrm{~min}(n$ $=5, P<0.01)$. APIII $\left(10^{-8} \mathrm{M}\right)$ alone did not affect the spontaneous uptake, but preincubation with APIII returned the stimulatory effect of AVP to baseline (AVP 13.04 \pm 0.92 to AVP + ANF $9.80 \pm 0.64 \times 10^{3} \mathrm{cpm} / \mathrm{mg}$ protein per $5 \mathrm{~min}, n=5, P$ $<0.01)$. APIII $\left(10^{-8} \mathrm{M}\right)$ did not affect ${ }^{45} \mathrm{Ca}^{2+}$ uptake by $10^{-7} \mathrm{M}$ AVP (data not shown). APIII $\left(10^{-9} \mathrm{M}\right)$ did not affect AVPstimulated uptake significantly $(12.70 \pm 0.48$ vs. $13.04 \pm 0.92$ $\times 10^{3} \mathrm{cpm} / \mathrm{mg}$ protein per $5 \mathrm{~min}, \mathrm{NS}$ ).

Vascular smooth muscle cell shape change. Addition of AVP to the medium-induced cell chape change in a dose-dependent manner (Fig. 5) (26). Cell shape change began at 3-5 min after the addition of AVP and was maximal after $20 \mathrm{~min}$. These changes in shape were characterized by a rounding of the cell body and the retraction of cell processes. With $10^{-8} \mathrm{M}$ AVP, $24.3 \pm 6.5 \%$ of the cells changed in response to the hormone. This percentage increased to $53.9 \pm 5.6 \%$ with $10^{-6} \mathrm{M}$ AVP. The average decrease in cell surface area for different hormone concentrations varied between $30.7 \%$ and $34.1 \%$; these differences were not significant and did not correlate with the concentration of AVP. APIII $\left(10^{-8} \mathrm{M}\right)$ virtually abolished contraction induced by $10^{-8}$ and $10^{-7} \mathrm{M}$ AVP. APIII (5 $\times 10^{-9} \mathrm{M}$ ) decreased the percentage of cells responding to $10^{-7}$ M AVP from $34.8 \pm 4.8 \%$ to $19.4 \pm 3.5 \%(P<0.05)$ (Fig. 6).

Cyclic nucleotide production. The production of cGMP and CAMP in aortic smooth muscle cells was measured in the

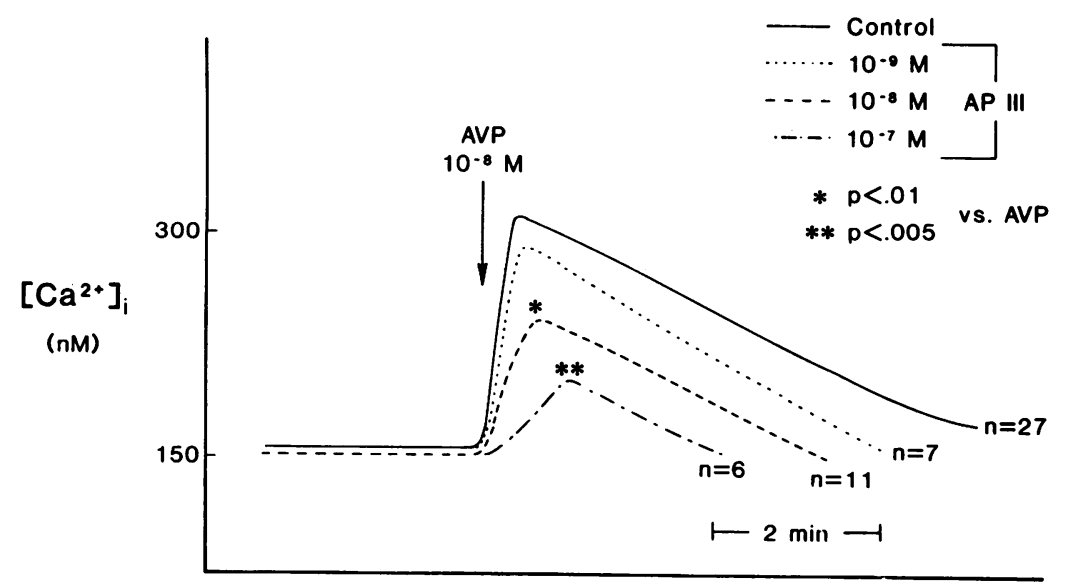

Figure 2. Effect of APIII on AVP-stimulated $\left[\mathrm{Ca}^{2+}\right]_{i}$. Each trace has been redrawn and represents a typical time course of $\left[\mathrm{Ca}^{2+}\right]_{i}$, with the mean peak value (6-11 experiments per group). Cells were preincubated for $5 \mathrm{~min}$ with APIII. APIII at the same concentration of that of preincubation was added simultaneously with AVP. 


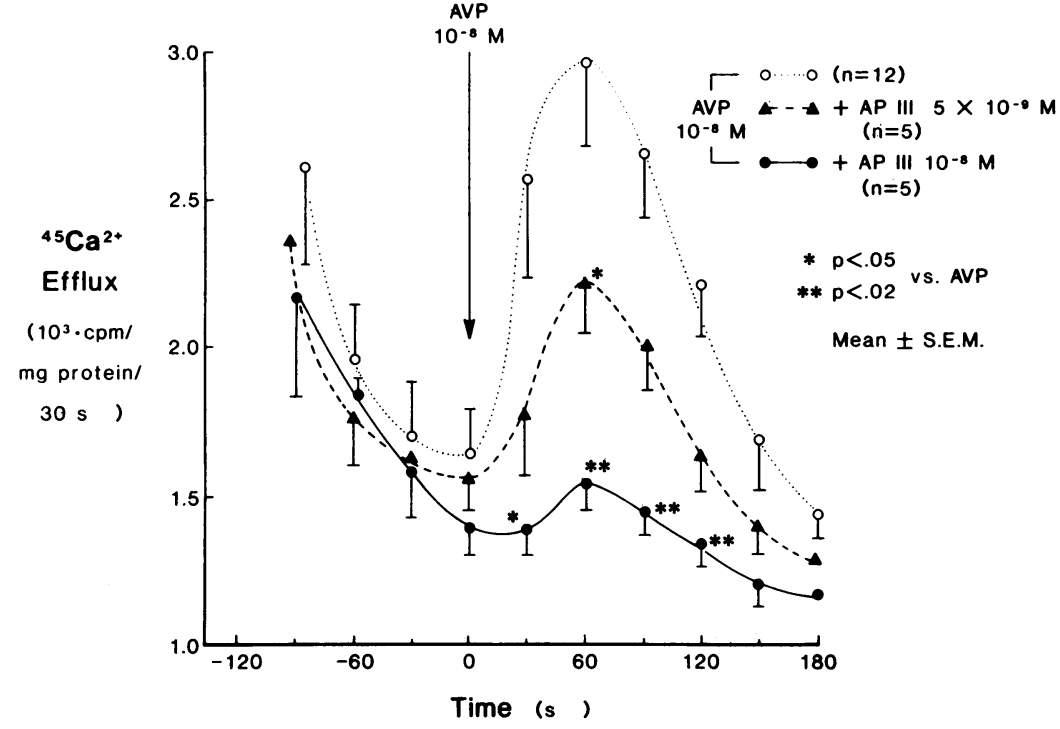

Figure 3. Effect of APIII on AVP-stimulated ${ }^{45} \mathrm{Ca}^{2+}$ efflux. AVP was added as indicated by the arrow. In the APIII groups, cells were preincubated with APIII for 10 min before the start of the measurements (five to nine experiments per group). presence of the phosphodiesterase inhibitor MIX $(0.5 \mathrm{mM})$ under basal conditions and in the presence of APIII. Basal cGMP production was $5.65 \pm 1.60 \mathrm{pmol} / \mathrm{mg}$ protein per 10 min and increased in a dose-dependent manner with APIII doses of $10^{-9}$ to $10^{-6} \mathrm{M}$ (Fig. 7). Basal cAMP production was $16.45 \pm 2.69 \mathrm{pmol} / \mathrm{mg}$ protein per $10 \mathrm{~min}(n=3)$ and was not stimulated by $10^{-7} \mathrm{M}$ APIII $(16.32 \pm 2.36 \mathrm{pmol} / \mathrm{mg}$ protein 10 per $\min , n=4)$.

Effects of 8-bromo cGMP on AVP-induced $\mathrm{Ca}^{2+}$ mobilization and cell shape change. Since the effect of APIII to attenuate AVP-induced $\mathrm{Ca}^{2+}$ mobilization and shape change in aortic smooth muscle cells was associated with increased cGMP production, the stable nucleotide 8-bromo cGMP (8bcGMP) was used to mimic the effects of APIII. Preincubation for 5 min with 8 bcGMP $\left(10^{-3}\right.$ and $\left.5 \times 10^{-3} \mathrm{M}\right)$ significantly attenuated AVP-stimulated increase $\left(10^{-8} \mathrm{M}\right)$ of $\left[\mathrm{Ca}^{2+}\right]_{\mathrm{i}}$ (Fig. 8). 8-bcGMP $\left(10^{-7} \mathrm{M}\right)$ also reduced the $10^{-7} \mathrm{M}$ AVP-induced increase of $\left[\mathrm{Ca}^{2+}\right]_{\mathrm{i}}$ by $45.2 \%(P<0.05), n=4 \cdot 10^{-3} \mathrm{M}$ 8 bcGMP had no effect on basal $\left[\mathrm{Ca}^{2+}\right]_{\mathrm{i}}$ (data not shown). 8bcGMP also attenuated the effect of AVP on ${ }^{45} \mathrm{Ca}^{2+}$ efflux (Fig. 9). The AVP-induced ${ }^{45} \mathrm{Ca}^{2+}$ uptake was also diminished by 8 bcGMP in a dose of $1.0^{-3} \mathrm{M}(13.04 \pm 1.42$ vs. $11.21 \pm 0.94 \times 10^{3} \mathrm{cpm} / \mathrm{mg}$ protein, $n=6, P<0.05$ ) (Fig. 10). $8 \mathrm{bcGMP}$ alone did not affect spontaneous ${ }^{45} \mathrm{Ca}^{2+}$ efflux and uptake (data not shown). Furthetmore, $8 \mathrm{bcGMP}\left(10^{-3} \mathrm{M}\right)$ attenuated AVP $\left(10^{-7} \mathrm{M}\right)$-induced cell contraction $(20.4 \pm 0.9 \%$ vs. $32.9 \pm 2.3 \%, n=5,10-17$ cells per experiment, $P<0.05$ ).

Methylene blue. Methylene blue, an inhibitor of soluble guanylate cyclase, was used in an attempt to inhibit the effects of APIII on AVP-stimulated $\mathrm{Ca}^{2+}$ mobilization and cell contraction. Methylene blue $\left(10^{-4} \mathrm{M}\right)$ did not block APIII $\left(10^{-8}\right.$ $\mathrm{M})$-stimulated cGMP production $(54.0 \pm 7.8$ vs. $55.1 \pm 12.3$ $\mathrm{pmol} / \mathrm{mg}$ protein per $10 \mathrm{~min}, n=4$, NS). Methylene blue also did not prevent the inhibitory effect of APIII on AVP-stimu-

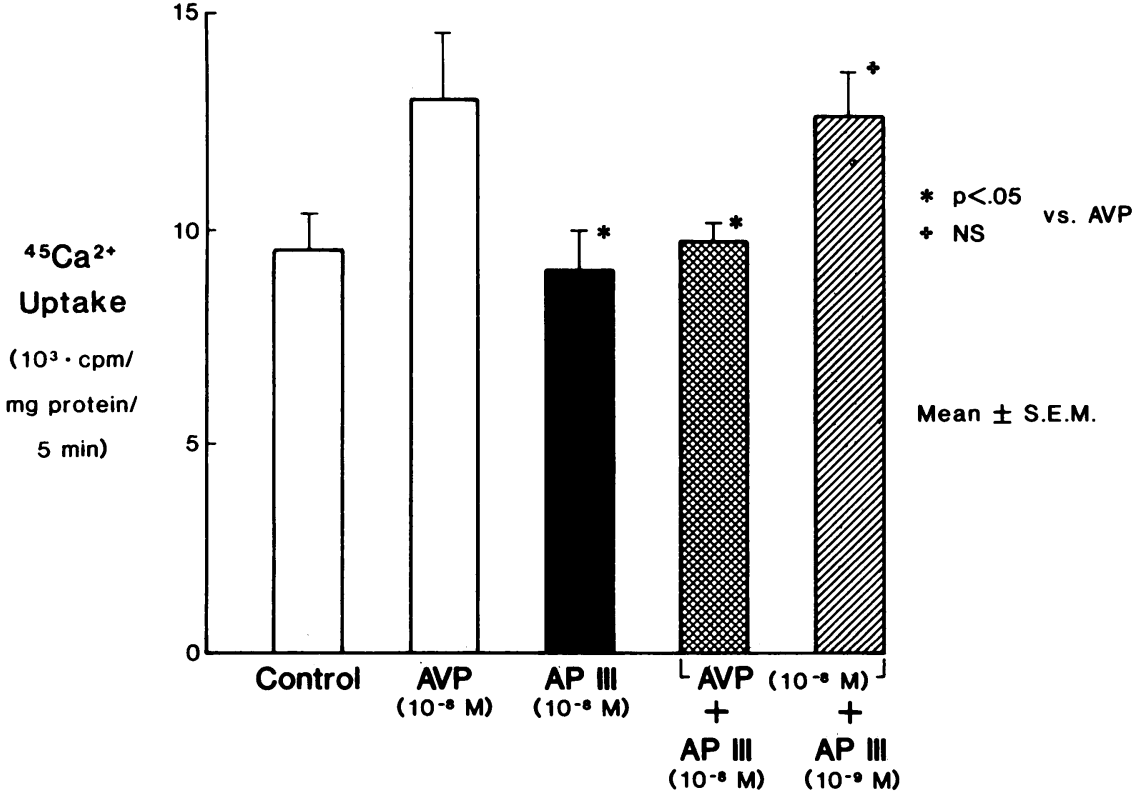

Figure 4. Effect of APIII on ${ }^{45} \mathrm{Ca}^{2+}$ uptake. Each column represents the mean \pm SEM of four to six determinations done in duplicate in separate cell cultures. 


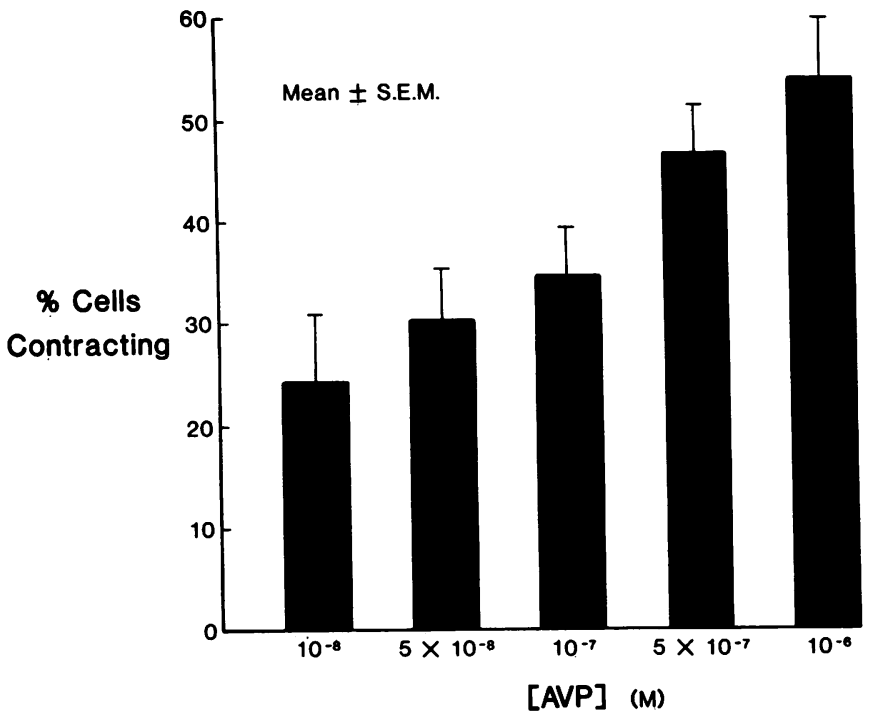

Figure 5. Dose-response curve of vascular smooth muscle cells in the presence of different concentrations of AVP. Each bar represents the mean $\pm S E M$ of at least five experiments.

lated ${ }^{45} \mathrm{Ca}^{2+}$ efflux (Fig. 8) or ${ }^{45} \mathrm{Ca}^{2+}$ uptake by APIII (Fig. 9). Furthermore, methylene blue had no effect on the inhibition of cell contraction by APIII (data not shown).

Inositol phosphates. The effect of APIII $\left(10^{-7} \mathrm{M}\right)$ on AVPinduced inositol phosphate's production is shown in Table I. APIII did not interfere with the AVP-mediated increase in $\mathrm{IP}_{2}$ and $\mathrm{IP}_{3}$, whereas a decrease in $\mathrm{IP}_{1}$ levels was observed $(P<0.05)$.

\section{Discussion}

The present in vitro studies were undertaken to examine whether APIII alters the AVP-induced cellular $\mathrm{Ca}^{2+}$ kinetics and cell contraction of rat vascular smooth muscle cells in culture. The vascular $\left(\mathrm{V}_{1}\right)$ receptors for AVP are known to increase the formation of $\mathrm{IP}_{3}$, which stimulates the intracellular release of $\mathrm{Ca}^{2+}$ from the sarcoplasmic reticulum (27-29).

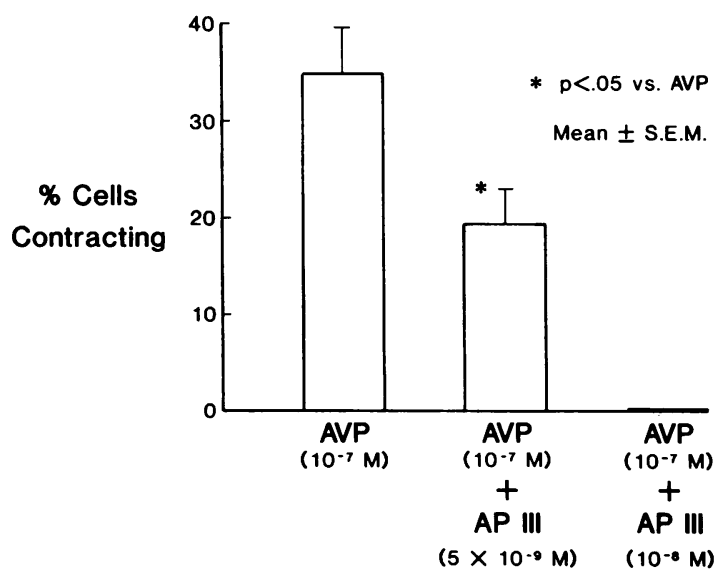

Figure 6. Effect of APIII on AVP $\left(10^{-7} \mathrm{M}\right)$-stimulated contraction of aortic smooth muscle cells $(n=5,10-17$ cells per experiment). Cells were preincubated with APIII for 10 min and APIII at the same concentration of the preincubation was added simultaneously with AVP.

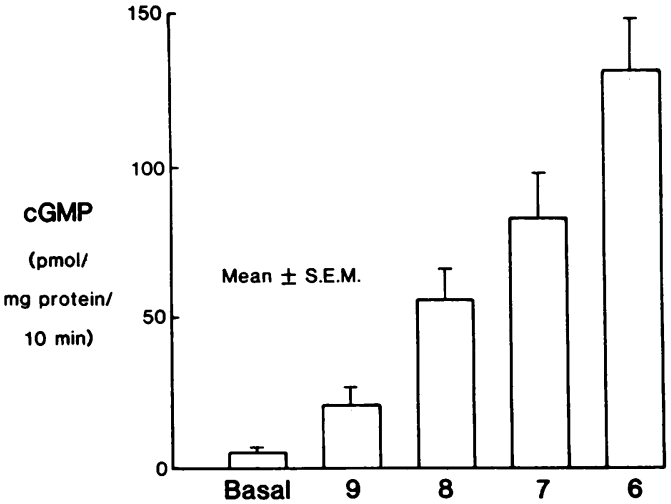

Figure 7. APIII-stimulated cGMP production in aortic smooth muscle cells. Each column represents the mean of three to four determinations done in triplicate in separate cell cultures in the presence of $0.5 \mathrm{mM}$ MIX.

This intracellular release of $\mathrm{Ca}^{2+}$ occurs in the absence of extracellular $\mathrm{Ca}^{2+}$ and is blocked by dantrolene, a known inhibitor of $\left[\mathrm{Ca}^{2+}\right]_{i}$ mobilization $(26,30,31)$. The $\mathrm{IP}_{3}$-induced $\mathrm{Ca}^{2+}$ release can be monitored by the rapid rise in cytosolic free $\mathrm{Ca}^{2+}$ as assessed by fluorescent dyes and the rapid cellular efflux of ${ }^{45} \mathrm{Ca}^{2+}$. Both cytosolic $\mathrm{Ca}^{2+}$ and $\mathrm{Ca}^{2+}$ efflux measurements were used in the present study to examine whether APIII alters this initial phase of contraction induced by AVP.

APIII attenuated in a dose-response manner both the AVP-induced rise in cytosolic free $\mathrm{Ca}^{2+}$ and ${ }^{45} \mathrm{Ca}^{2+}$ efflux. Quin 2 and fura 2 fluorescent dyes were used to assess cytosolic free $\mathrm{Ca}^{2+}$ in the present study and the results were similar. Other investigators have also shown in glomerular mesangial cells that results were similar when $\left[\mathrm{Ca}^{2+}\right]_{\mathrm{i}}$ was assessed by these same indicators (32). No effect of APIII alone could be demonstrated on either cytosolic free $\mathrm{Ca}^{2+}$ or ${ }^{45} \mathrm{Ca}^{2+}$ efflux, results similar to those observed by other authors $(33,34)$. These in vitro data are compatible with the in vivo observations that the vasodilatory effect of the atrial peptides is most easily demonstrable in the presence of vasoconstrictor hormones (12). Also, ANF has been reported to interfere with $\mathrm{Ca}^{2+}$ mobilization and contraction by norepinephrine $(34,35)$, histamine (34), and AII (33), although for AII the evidence is not consistent $(34,36,37)$.

The effect of APIII to decrease both the AVP-induced rise in cytosolic free $\mathrm{Ca}^{2+}$ and ${ }^{45} \mathrm{Ca}^{2+}$ efflux suggested an inhibitory effect on either $\mathrm{IP}_{3}$ generation or the effect of $\mathrm{IP}_{3}$ to increase

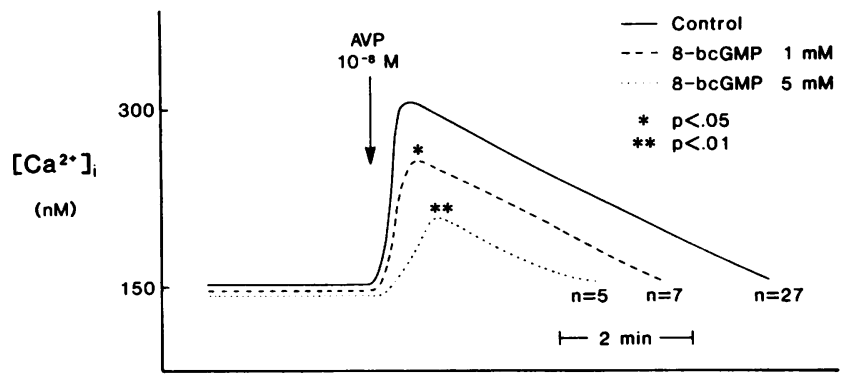

Figure 8. Effect of 8-bromo cGMP on AVP-stimulated $\left[\mathrm{Ca}^{2+}\right]_{\mathrm{i}}$. Each trace has been redrawn and represents a typical time course of $\left[\mathrm{Ca}^{2+}\right]_{\mathrm{i}}$ with the mean peak value $(n=5)$. 


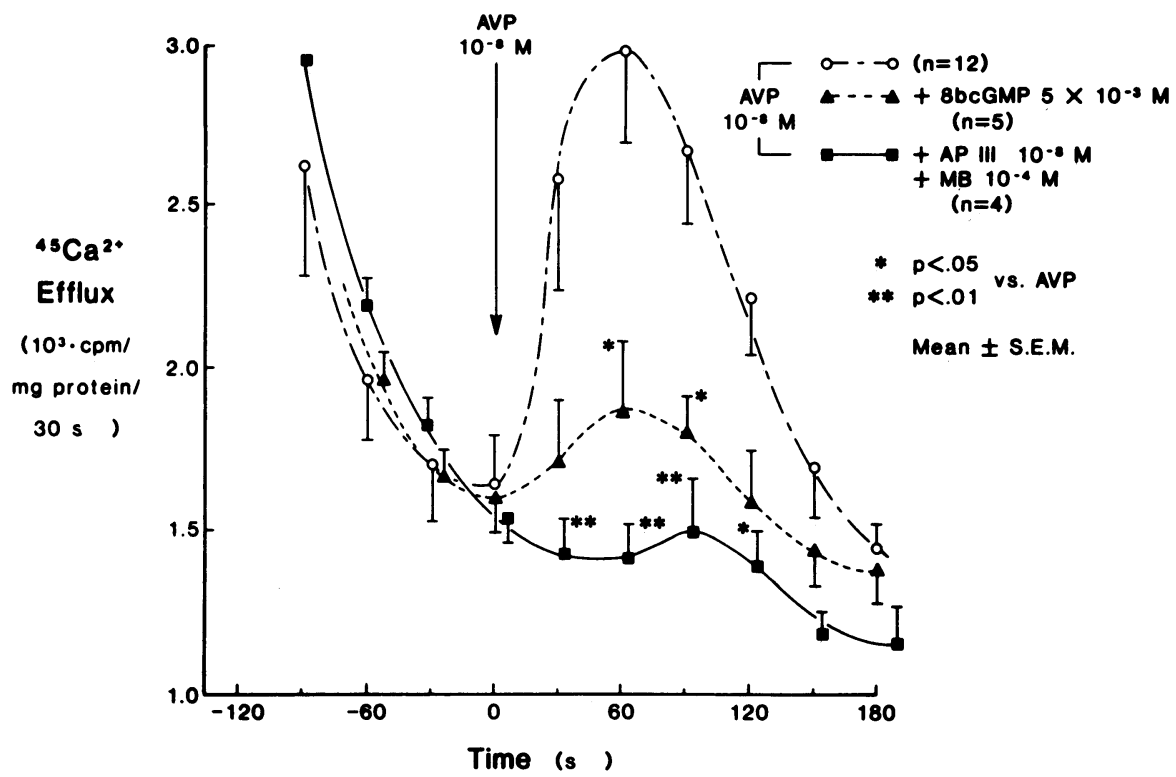

Figure 9. ${ }^{45} \mathrm{Ca}^{2+}$ efflux. Effect of 8-bromo cGMP on AVP-induced ${ }^{45} \mathrm{Ca}^{2+}$ efflux and inhibition of AVP-induced efflux by APIII in the presence of methylene blue (four to nine experiments per group).
$\mathrm{Ca}^{2+}$ release from the sarcoplasmic reticulum. Even though we did not find a decrease in $\mathrm{IP}_{3}$ production by AVP in cells pretreated with ANF, the observed decrease in $\mathrm{IP}_{1}$, a metabolite of $\mathrm{IP}_{3}$, suggests that an earlier decrease of $\mathrm{IP}_{3}$ could have occurred. The issue of the role of ANF on inositol phosphates metabolism is still controversial. Experiments in glomerular mesangial cells did not detect an effect of APII to alter AVPinduced $\mathrm{IP}_{3}$ generation (37). Although these latter results were obtained in mesangial, not aortic smooth muscle cells, and with APII not APIII, they suggest that atrial peptides may act by a mechanism distal to $\mathrm{IP}_{3}$ production, e.g., the endoplasmic reticulum or the contractile apparatus. In this regard, it is interesting to note that cGMP, the purported secondary messenger of atrial peptides, has been proposed to alter sarcoplasmic $\mathrm{Ca}^{2+}$ release $(38,39)$ and to modify the kinetics of membrane $\mathrm{Ca}^{2+}$ transport (40). However, there are other reports showing that ANF (41) or its putative second messenger cGMP (42) may cause a decrease in inositol phosphatide breakdown. This could account for the reduction in $\mathrm{Ca}^{2+}$ release by AVP and other hormones.

Further studies were therefore performed in the present investigation to examine whether cGMP might be involved in these effects whereby APIII alters AVP-induced $\mathrm{Ca}^{2+}$ kinetics in rat aortic vascular smooth muscle. As in previous studies $(15,16)$, the present results support the findings that atrial peptides stimulate cGMP but not cAMP in vascular smooth muscle. The effect of APIII to stimulate cGMP was demonstrated to be dose-dependent and the $10^{-8} \mathrm{M}$ dose of APIII that inhibited AVP-induced $\mathrm{Ca}^{2+}$ kinetics and cell contraction also increased cGMP. This observation therefore was compatible with the possibility that cGMP might be involved in the observed interactions of ANF and AVP on cellular $\mathrm{Ca}^{2+}$ kinetics.

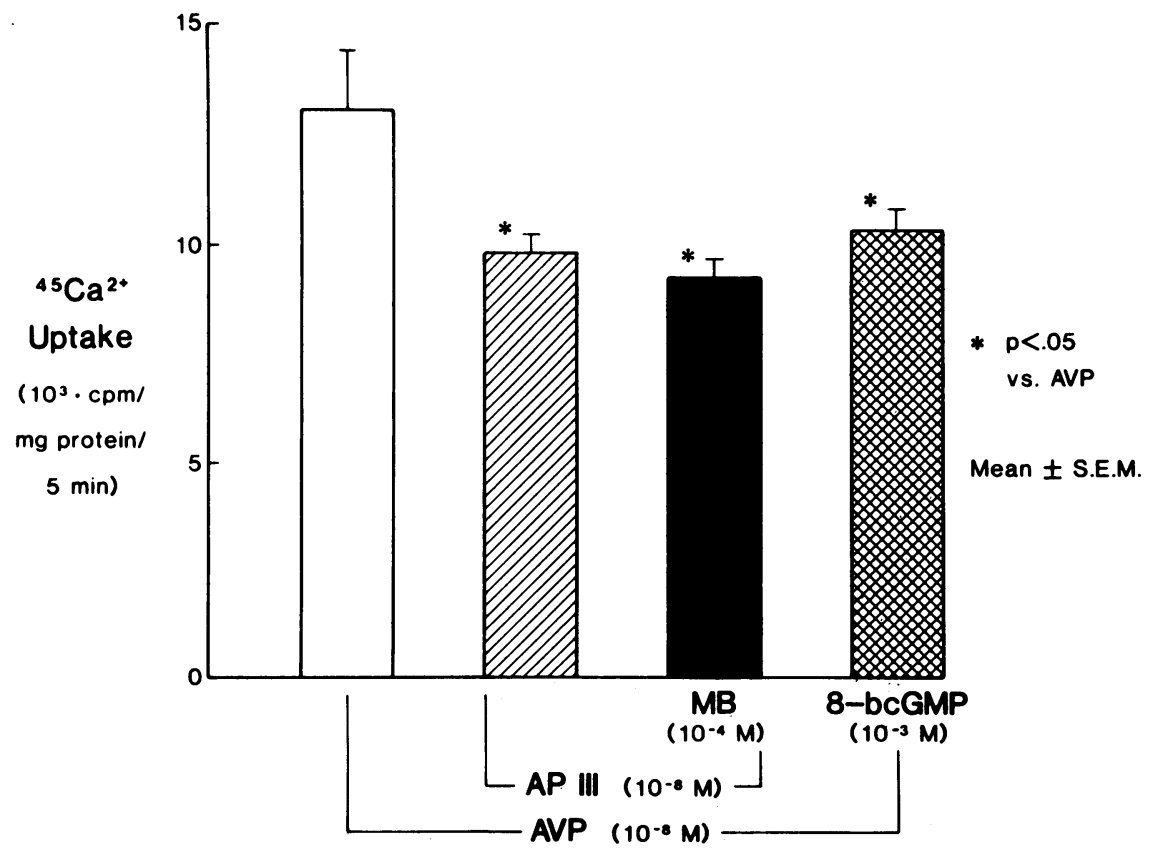

Figure 10. 8-bromo cGMP mimics the effect of APIII on AVP-induced ${ }^{45} \mathrm{Ca}^{2+}$ uptake (crosshatched bar). Methylene blue does not affect inhibition of AVP-induced ${ }^{45} \mathrm{Ca}^{2+}$ uptake by APIII (solid bar). Each bar represents the mean \pm SEM of four to six determinations done in duplicate in separate cell cultures. 
Table I. Effect of ANF on AVP-mediated Inositol Phosphate Production

\begin{tabular}{|c|c|c|c|c|}
\hline & AVP $10^{-7} \mathrm{M}$ & $\begin{array}{c}\text { AVP } 10^{-7} \mathbf{M} \\
+ \text { ANF } 10^{-7} \mathbf{M}\end{array}$ & AVP $10^{-8} \mathrm{M}$ & $\begin{array}{r}\text { AVP } 10^{-8} \mathrm{M} \\
+ \text { ANF } 10^{-7} \mathrm{M}\end{array}$ \\
\hline & \multicolumn{4}{|c|}{ counts $/ 10^{4}$ total counts per $\mu \mathrm{g}$ protein } \\
\hline $\mathrm{IP}_{1}$ & $433 \pm 31$ & $327 \pm 36^{*}$ & $342 \pm 19$ & $246 \pm 37^{*}$ \\
\hline $\mathrm{IP}_{2}$ & $80 \pm 13$ & $84 \pm 12$ & $51 \pm 5$ & $54 \pm 7$ \\
\hline $\mathrm{IP}_{3}$ & $88 \pm 14$ & $100 \pm 24$ & $50 \pm 7$ & $58 \pm 10$ \\
\hline
\end{tabular}

$n=8$.

${ }^{*} P<0.05$ respective to the same AVP concentration in the absence of ANF.

The effect of the stable cGMP analogue, 8bcGMP, on AVPinduced ${ }^{45} \mathrm{Ca}^{2+}$ efflux and cytosolic free $\mathrm{Ca}^{2+}$ was therefore examined. 8bcGMP decreased AVP-induced ${ }^{45} \mathrm{Ca}^{2+}$ efflux and cytosolic free $\mathrm{Ca}^{2+}$ concentration and cell shape change. The effective doses of $8 \mathrm{bcGMP}$ were, however, quite large, i.e., 1 and $5 \mathrm{mM}$, thus a pharmacological rather than physiological effect of the agent cannot be excluded. The concentrations of the 8bcGMP at the intracellular target sites may, however, have been in the normal range for cGMP.

Whereas some investigators have suggested that soluble guanylate cyclase may be responsible for the effect of atrial peptides to stimulate cGMP $(43,44)$, other results suggest that particulate guanylate cyclase is involved $(16,44)$. In the present studies, the absence of an effect of methylene blue, an inhibitor of soluble guanylate cyclase, suggests that, if cGMP modulates the interaction between APIII and AVP, it is the particulate rather than soluble guanylate cyclase which is involved. However, the possibility of the existence of noncGMP-mediated effects of AVP must be taken into account, as suggested by recent reports (46).

In the present study APIII was also shown to diminish the effect of AVP to increase ${ }^{45} \mathrm{Ca}^{2+}$ uptake in a dose-response manner. Thus, while $10^{-8} \mathrm{M}$ APIII blocked the cellular uptake induced by $10^{-8} \mathrm{M}$ AVP, $10^{-9} \mathrm{M}$ APIII did not block this effect of the same dose of AVP. Such reduction in $\mathrm{Ca}^{2+}$ uptake may account in part for the decreased $\left[\mathrm{Ca}^{2+}\right]_{\mathrm{i}}$ peak observed with the fluorescent indicators. Taylor and Meisheri (47) reported that APII inhibits norepinephrine-induced ${ }^{45} \mathrm{Ca}^{2+}$ uptake by aortic rings. Furthermore, these investigators found that APII is much less effective in inhibiting potassium-induced ${ }^{45} \mathrm{Ca}^{2+}$ uptake thus suggesting that atrial peptides may interfere primarily with receptor-operated rather than voltagedependent channels.

The apparent discrepancy between the concentrations of ANF that inhibit cell shape change and those that reduced $\mathrm{Ca}^{2+}$ mobilization is suggestive of an ANF action beyond the $\mathrm{Ca}^{2+}$-releasing mechanisms. Similar results have been recently reported by Takuwa and Rasmussen (34), who found a strong inhibitory effect of ANF on the AII-dependent rat aortic contraction, in the absence of a decrease in AII-stimulated $\mathrm{Ca}^{2+}$ transient. As a control in the present study, the effect of ANF on AII-induced $\left[\mathrm{Ca}^{2+}\right]_{i}$ was examined and these previous results (33) were confirmed. Furthermore, the partial reduction by ANF of the AVP-mediated $\left[\mathrm{Ca}^{2+}\right]_{\mathrm{i}}$ increase was unlikely to explain totally the inhibition of cell shape change with ANF. Specifically, the $\left[\mathrm{Ca}^{2+}\right]_{i}$ transient induced by AVP in the pres- ence of ANF, although reduced, was still in the range which is associated with cell activation.

In summary, ANF may interfere with the initial phase of AVP-induced vascular contraction by diminishing cellular $\mathrm{Ca}^{2+}$ mobilization, perhaps by impairing the effect of $\mathrm{IP}_{3}$ on the endoplasmic reticulum. The present results, however, also incriminate another effect(s) oi ANF to block vascular contraction caused by AVP. This latter effect of ANF appears to be different than the initial $\mathrm{Ca}^{2+}$ mobilization by $\mathrm{IP}_{3}$, and may involve protein kinase activation and diminished cellular $\mathrm{Ca}^{2+}$ influx.

\section{Acknowledgments}

The authors wish to thank Dr. Michael S. Anger for performing the cAMP radioimmunoassay and Ms. Linda $\mathbf{M}$. Benson for secretarial assistance.

This work was supported by a grant from the National Institutes of Health DK-19928. Dr. H. Meyer-Lehnert is a recipient of a fellowship from the Deutsche Forschungsgemeinschaft; Dr. C. Caramelo is a recipient of a Fulbright Fellowship from the Education and Science Ministry of Spain.

\section{References}

1. Ballermann, B. J., and B. M. Brenner. 1985. Biologically active atrial peptides. J. Clin. Invest. 76:2041-2048.

2. Maack, T., M. J. F. Camargo, H. D. Kleinert, J. H. Laragh, and S. A. Atlas. 1985. Atrial natriuretic factor: structure and functional properties. Kidney Int. 27:607-615.

3. Needleman, P., S. P. Adams, B. R. Cole, M. G. Currie, D. M. Geller, M. L. Michener, C. B. Saper, D. Schwartz, and D. G. Standaert. 1985. Atriopeptins as cardiac hormones. Hypertension. 7:469-482.

4. Bianchi, G., J. Gutkowska, R. Garcia, G. Thibault, J. Genest, and M. Cantin. 1985. Radioautographic localization of ${ }^{125}$ I-atrial natriuretic factor (ANF) in rat tissues. Histochemistry. 82:441-446.

5. Hirata, Y., M. Tomita, H. Yoshima, and M. Ikeda. 1984. Specific receptors for atrial natriuretic factor (ANF) in cultured vascular smooth muscle cells of rat aorta. Biochem. Biophys. Res. Commun. 125:562-568.

6. Leitman, D. C., S. A. Waldman, T. Kuno, and F. Murad. 1985. Specific atrial natriuretic factor receptors mediate increased cyclic GMP accumulation in cultured bovine aortic endothelial and smooth muscle cells. Clin. Res. 33:599a. (Abstr.)

7. Schiffrin, E. L., L. Chartier, G. Thibault, J. St.-Louis, M. Cantin, and J. Genest. 1985. Vascular and adrenal receptors for atrial natriuretic factor in the rat. Circ. Res. 56:801-807.

8. Napier, M. A., R. L. Vandlen, G. Albers-Schlonberg, R. F. Nutt, S. Brady, T. Lyle, R. Winquist, E. R. Faison, L. A. Heinel, and E. H. Blaine. 1984. Specific membrane receptors for atrial natriuretic factor in renal and vascular tissues. Proc. Natl. Acad. Sci. USA. 81:58465950.

9. Camargo, M. J. F., H. D. Kleinert, S. A. Atlas, J. E. Sealey, J. H. Laragh, and T. Maack. 1984. Ca-dependent hemodynamic and natriuretic effects of atrial extract in isolated rat kidney. Am. J. Physiol. 246:F447-F456.

10. Garcia, R., G. Thibault, M. Cantin, and J. Genest. 1984. Effect of a purified atrial natriuretic factor on rabbit vascular strips and vascular beds. Am. J. Physiol. 247:R34-R39.

11. Currie, M. G., D. M. Geller, B. R. Cole, J. G. Boylan, W. YuSheng, S. W. Holmberg, and P. Needleman. 1983. Bioactive cardiac substances: potent activity in mammalian atria. Science (Wash. DC). 221:71-73.

12. Winquist, R. J. 1985. The relaxant effects of atrial natriuretic factor on vascular smooth muscle. Life Sci. 37:1081-1087.

13. Wakitani, K., B. R. Cole, D. M. Geller, M. G. Currie, S. P. 
Adams, K. F. Fok, and P. Needleman. 1985. Atriopeptins: correlation between renal vasodilation and natriuresis. Am. J. Physiol. 249:F49F53.

14. Oshima, T., M. G. Currie, D. M. Geller, and P. Needleman. 1984. An atrial peptide is a potent renal vasodilator substance. Circ. Res. 54:612-616.

15. Waldman, S. A., R. M. Rapoport, and F. Murad. 1984. Atrial natriuretic factor selectively activates particulate guanylate cyclase and elevates cyclic GMP in rat tissues. J. Biol. Chem. 259:14322-14334.

16. Winquist, R. J., E. P. Faison, S. A. Waldman, K. Schwartz, F. Murad, and R. M. Rapoport. 1984. Atrial natriuretic factor elicits an endothelium-independent relaxation and activates particulate guanylate cyclase in vascular smooth muscle. Proc. Natl. Acad. Sci. USA. 81:7661-7664.

17. Chamley, J. H., G. R. Campbell, J. D. McConell, and U. Groschel-Stewart. 1977. Comparison of vascular smooth muscle cells from adult human, monkey, and rabbit in primary culture and in subculture. Cell. Tissue Res. 177:503-522.

18. Chamley-Campbell, J. H., G. R. Campbell, and R. Ross. 1979. The smooth muscle cell in culture. Physiol. Rev. 59:1-61.

19. Tsien, R., T. Pozzan, and T. Rink. 1982. Calcium homeostasis in intact lymphocytes. Cytoplasmic free calcium monitored with a new intracellularly trapped fluorescent indicator. J. Cell. Biol. 94:325-334.

20. Gabella, G. 1981. In Smooth Muscle: An Assessment of Current Knowledge. E. Bulbring, A. F. Brading, A. W. Jones, and T. Tomita, editors. Edward Arnold, London. 1-46.

21. Moolenaar, W. H., L. G. Y. Tertoolen, and S. W. deLast. 1984. Growth factors immediately raise free $\mathrm{Ca}^{2+}$ in human fibroblasts. $J$. Biol. Chem. 259:8066-8069.

22. Grynkiewicz, G., M. Poenie, and R. Y. Tsien. 1985. A new generation of $\mathrm{Ca}^{2+}$ indicators with greatly improved fluorescence properties. J. Biol. Chem. 260:3440-3450.

23. Bingham-Smith, J., and T. M. Lincoln. 1987. Angiotensin decreases cyclic GMP production by atrial natriuretic factor. Am. J. Physiol. 253:C147-C150.

24. Lowry, O. H., N. Y. Rosebrough, A. L. Farr, and R. J. Randall. 1951. Protein measurement with the Folin phenol reagent. J. Biol. Chem. 133:265-272.

25. Rhodes, D., V. Prpic, J. M. Exton, and P. F. Blackmore. 1983. Stimulation of phosphatidylinositol 4,5-bisphosphate hydrolysis in hepatocytes by vasopressin. J. Biol. Chem. 258:2770-2773.

26. Takeda, K., H. Meyer-Lehnert, J. K. Kim, and R. W. Schrier. 1988. Effect of angiotensin II on $\mathrm{Ca}^{2+}$ kinetics and contraction in cultured rat glomerular mesangial cells. Am. J. Physiol. 254:F254F266.

27. Nabika, T., P. A. Velletri, W. Lovenberg, and M. A. Beaven. 1985. Increase in cytosolic phosphoinositide metabolism induced by antiogensin II and [Arg]-vasopressin in vascular smooth muscle cells. J. Biol. Chem. 260:4661-4670.

28. Doyle, V. M., and U. T. Ruegg. 1985. Vasopressin-induced production of inositol trisphosphate and calcium efflux in a smooth muscle cell line. Biochem. Biophys. Res. Commun. 131:469-476.

29. Smith, J. B., L. Smith, and B. L. Higgins. 1985. Temperature and nucleotide dependence of calcium release by myo-inositol 1,4,5trisphosphate in cultured vascular smooth muscle cells. J. Biol. Chem. 260:14413-14416.

30. Ally, A. I., D. F. Horrobin, M. S. Manku, R. O. Morgan, M. Karmazyn, R. Karmali, and S. C. Cunnane. 1978. Dantrolene blocks intracellular calcium release in smooth muscle: Competitive antagonism of thromboxane $\mathrm{A}_{2}$. Can. J. Physiol. Pharmacol. 56:520-523.

31. Tengupta, C., U. A. Meyer, and E. Carafoli. 1980. Binding of dantrolene sodium to muscle intracellular membranes. FEBS (Fed. Eur. Biochem. Soc.) Lett. 117:37-38.

32. Bonventre, J. V., K. L. Skorecki, J. T. Kreisberg, and J. Y. Cheung. 1986. Vasopressin increases cytosolic free calcium concentration in glomerular mesangial cells. Am. J. Physiol. 251:F94-F102.

33. Knorr, M., R. Locher, M. Stimpel, D. Edmonds, and W. Vetter. 1986. Effect of atrial natriuretic polypeptide on angiotensin II-induced increase of cytosolic free calcium in cultured smooth muscle cells. J. Hypertension. 4(Suppl. 2):S67-S69.

34. Takuwa, Y., and H. Rasmussen. 1987. Measurement of cytoplasmic free $\mathrm{Ca}^{2+}$ concentration in rabbit aorta using the photoprotein, aequorin. J. Clin. Invest. 80:248-257.

35. Chiu, P. J. S., G. Tetzloff, and E. J. Sybertz. 1986. The effects of atriopeptin II on calcium fluxes in rabbit aorta. Eur. J. Pharmacol. 124:277-284.

36. Capponi, A. M., P. D. Lew, R. Nuthrich, and M. B. Vallotton. 1986. Effects of atrial natriuretic peptide on the stimulation of angiotensin II of various target cells. J. Hypertension. 4(Suppl. 2):S61-S65.

37. Kreisberg, J. I., P. Y. Patel, M. A. Venkatachalam, and D. A. Troyer. 1987. Synthetic atrial peptide (APII) fails to inhibit inositol trisphosphate $\left(\mathrm{IP}_{3}\right)$ release and contraction induced by vasopressin $(\mathrm{V})$ in cultured mesangial (MS) cells. Kidney Int. 31:277. (Abstr.)

38. Lincoln, T. M. 1983. Effects of sodium nitroprusside and 8bromo cyclic GMP on the contractile activity of the rat aorta. J. Pharmacol. Exp. Ther. 224:100-107.

39. Murad, F., R. M. Rapoport, and R. Fiscus. 1985. Role of cyclic GMP in relaxation of vascular smooth muscle. J. Cardiovasc. Pharmacol. 7(Suppl. 3):S111-S118.

40. Furukawa, K. I., and M. Nakamura. 1987. Cyclic GMP regulation of the plasma membrane $\left(\mathrm{Ca}^{2+}-\mathrm{Mg}^{2+}\right)$ ATPase in vascular smooth muscle. J. Biochem. 101:287-290.

41. Barnett, R., P. Ortiz, G. Lollo, and L. Ramsammy. 1988. Atrial natriuretic factor antagonizes angiotensin II-mediated phosphoinositide changes in cultured rat mesangial cells (abstract). Kidney Int. 33:253.

42. Rapoport, R. M. 1986. Cyclic guanosine monophosphate inhibition of contraction may be mediated through inhibition of phosphatidylinositol hydrolysis in rat aorta. Circ. Res. 58:407-410.

43. Stokes, T. J., C. L. McConkey, and K. J. Martin. 1986. Atriopeptin III increases CGMP in glomeruli but not in proximal tubules of dog kidney. Am. J. Physiol. 250:F27-F31.

44. Ohlstein, E. H., and B. A. Berkowitz. 1985. Cyclic guanosine monophosphate mediates vascular relaxation induced by atrial natriuretic factor. Hypertension. 7:306-310.

45. Waldman, S. A., R. M. Rapoport, and F. Murad. 1984. Atrial natriuretic factor selectively activates particulate guanylate cyclase and elevates cyclic GMP in rat tissues. J. Biol. Chem. 259:14332-14334.

46. Rockwat, T. W., V. K. Sarin, and W. H. Holeman. 1987. Divergence of ANF analogs in smooth muscle cell cGMP response and aorta vasorelaxation: evidence for receptor subtypes. Biochem. Biophys. Res. Commun. 144:422-431.

47. Taylor, C. J., and K. D. Meisheri. 1986. Inhibitory effects of synthetic atrial peptide on contractions and ${ }^{45} \mathrm{Ca}$ fluxes in vascular smooth muscle. J. Pharmacol. Exp. Ther. 237:803-808. 